\title{
STEERING BY EVALUATION IN TIMES OF IMPACT ORIENTATION AND MONITORING?
}

\author{
ANGELA WROBLEWSKI \& ANKE LIPINSKY
}

\section{ABSTRACT}

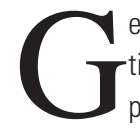
ender equality is a goal of German and Austrian higher education policy, which is currently being shaped by decentralised policy implementation and a distinct orientation on impact. In this article, we discuss the contribution that evaluation can make to the interplay between the two. In doing so, we draw on the evaluations of two gender equality policies aimed at increasing the share of women professors. Using these two examples, we demonstrate the role that evaluation can play with regard to policy steering in a setting characterised by decentralised policy implementation and impact orientation. Our focus thereby lies not just on the use of evaluation results by the commissioning bodies but also on the acceptance and use of evaluations and their associated instruments (e.g. indicators) by the higher education institutions themselves, thereby allowing evaluation to contribute to a general discourse on gender equality politics.

\section{INTRODUCTION}

Gender equality policies in higher education have been characterised for some years by efforts that can be subsumed under the term "from government to governance", in both, Austria and Germany. The aim is to transfer responsibilities for the development and implementation of gender equality policies from a ministerial to a university/higher education level.

In Austria, this has been achieved through the implementation of the Universities Act 2002 (Universitätsgesetz 2002, UG 2002; Kasparovsky, Stand: 1. Jänner 2013), which gave far reaching autonomy to the country's universities. The latter can now make their own budgetary and personnel decisions and are also responsible for the development of measures to achieve gender equality and their implementation (Höllinger \& Titscher, 2004). This change required a fundamental realignment of universities gender equality policies (Ulrich, 2006), since the central player therein prior to UG 2002 had been the Ministry of Science, which established anti-discrimination and gender research bodies (e.g. equal opportunities working groups and coordination units for women's and gender research respectively, at universities) and initiated and funded pilot projects (Wroblewski, Gindl, Leitner, Pellert, \& Woitech, 2007). Today, the Ministry of Science can only formulate overarching goals, such as the principles of gender mainstreaming and promotion of women that are anchored in UG 2002, and try to stimulate their implementation in higher education steering instruments like performance agreements ${ }^{1}$

This autonomy went hand in hand with the expectation that gender equality policy would focus more strongly on the respective university's own specific situation and thus be designed more effectively. It also aimed to support an orientation on good practices at other universities, i.e. to strengthen the competitive element by monitoring and comparing universities (Höllinger \& Titscher, 2004). Hence, the years following the implementation of UG 2002 - despite the statutory definition of equal opportunities bodies - under the provisions of UG 2002 (each university must set up an equality opportunities working group and a coordination unit for women's and gender research and publish a plan to advance women) - led to a broad range of different equal opportunities policies at universities, with clear differences in focus, allocation of resources and commitment (Tiefenthaler \& Good, 2011).

This development coincided with the realignment of public budgets to the principle of impact orientation to ensure more efficient deployment of public monies. Each ministry formulated at least one genderrelated impact goal, with the Science Ministry setting the goal of achieving a "gender balance in leadership positions, committees and young scientists/artists". This was to be achieved through increasing the share of women professors, the share of women in leadership positions/on university committees as well as the share of women in Laufbahnstellen tenure track positions leading to assistance professorships (Wroblewski 2016). Each university's contribution to this goal is defined in its respective performance agreement.

In Germany, the Higher Education Framework Act of 1999 amended higher education law and cooperation between the federal government and the federal states (Länder) in the higher education system - with far-reaching consequences for equal opportunities policy. Until the mid2000s, equal opportunities policy in higher education was shaped by state regulations and federal and Länder programmes respectively. The reform of German federalism, which assigned the Länder more legal authority and a larger budget for higher education institutions than before, led to an end of the country's Higher Education and Research Programme's for Equal Opportunities (Hochschul- und Wissenschaftsprogramm; HWP). This resulted in an absence of nationwide stimuli and resources for improving gender equality at higher education establishments. At the same time, numerous scientific stakeholders published "their" approach to equal opportunities in research. The different positions and initiatives to improve gender equality developed lively dynamics that also attracted media attention (Dalhoff, Lipinsky, Löther, \& Steinweg, 2015). 
While some Länder established their own programmes to promote equal opportunities and/or female academics, the federal government and all Länder decided to launch and jointly finance the so-called Programme for Women Professors (Professorinnenprogramm) as the legal provisions allow for cooperation in matters of national relevance ${ }^{2}$.

The higher education and federalism reforms led to a proliferation of equal opportunities agents in the German higher education system and were also intended to trigger competition between universities. One consequence was the emergence of a multitude of different equal opportunities structures in the universities. Some universities set up gender/ diversity offices, usually in parallel with already established women's and equal opportunities units. Since then, differentiated priorities and complex practices to promote equal opportunities have emerged (Lipinsky, 2017): not least with the aid of political and financial stimuli from the government's excellence initiative (Engels, 2009; Engels, Beaufaÿs, Kegen, \& Zuber, 2015; Engels, Ruschenburg, \& Zuber, 2012; Kibler, 2011), the Research-Oriented Standards on Gender Equality implemented by the German Research Foundation (Deutsche Forschungsgemeinschaft (DFG), 2014; Simon, 2011), the afore-mentioned Programme for Women Professors (Löther \& Glanz, 2017; Zimmermann, 2012) and the recommendations of the German Council of Science and Humanities on equal opportunities for scientists and academics (Wissenschaftsrat, 2007; Wissenschaftsrat, 2012). At Länder level, equal opportunities indicators appear in target agreements between higher education establishments and the Länder as performance indicators for the performance-based allocation of funds. ${ }^{3}$

The role played by evaluation in the new coordination mechanisms between higher education institutions and the state is broad and varied (Roßmann, 2013). In an ideal scenario, an evaluation reveals both, the reasons for and scope of any intended/unintended effects. Those who commission such evaluations oftentimes give preference to quantitative indicators when it comes to determining changes or identifying the "successes" of the programme. However, a focus on quantitative success indicators alone does not reveal the causes of the intended impact and thus leads to a potential distortion of the effects of a programme ( cf. Weiss, Murphy-Graham, Petrosino, \& Gandhi, 2008), since these cannot show what actually led to the changes. To produce a validated causal chain, i.e. to link causes to effects, the interpretation of the results (aka "successes") must look at how the higher education institutions actually handled the requirements of the programme and which element(s) of it had a steering effect in the university or beyond.

In both Austria and Germany, the situation in the higher education sector is characterised by a trend towards the decentralisation of equal opportunities policy and a corresponding management by objectives approach in which the continuous monitoring of target achievements plays a central role. In this article, we look at the role evaluation can play in this interplay of decentralised policy implementation and impact orientation. To do so, we take a critical look at evaluations of two staterun equal opportunities programmes, both aimed at raising the share of women professors and institutionalising equal opportunities policy. The two evaluations in question relate to the "excellentia" programme in
Austria (Wroblewski, 2010) and the "Programme for Women Professors" in Germany (Löther \& Glanz, 2017; Zimmermann, 2012). We will begin in a first step by describing each of these evaluations in detail (object of the evaluation, context, evaluation design, results) followed by a second step of discussing the role of evaluation in an impact oriented setting using our two case studies as examples.

\section{TWO EVALUATION CASE STUDIES}

\subsection{EVALUATION OF "EXCELLENTIA"}

Object of the evaluation: excellentia was a programme run by the Austrian Ministry of Science from 2006 to 2011 to raise the share of women professors. Its goal was to make use of forthcoming retirements to significantly raise the share of women in professorships (to $26 \%$, i.e. double that of the reference year 2003). For each additional female professor appointed, the universities received a one-off bonus of between 30,000 and 70,000 euros, which they were free to use as they saw fit. In most cases, this money was used for measures to support women (e.g. grants for female PhD students). The programme managers did not assume that the financial incentive would trigger a direct increase in the share of female professors. Instead, excellentia worked on the assumption that it would serve to "reward" those universities which had looked at the reasons for the underrepresentation of women in their appointment procedures and had developed and implemented any necessary countermeasures.

Goal and purpose of the evaluation: This was an accompanying and responsive evaluation, i.e. it was intended to deliver early indications and pointers for optimising the programme. The first interim report (Wroblewski \& Leitner, 2007) therefore focused on the acceptance of the programme by the relevant stakeholders at the universities. The 2009 and 2010 reports contain the results of the case studies at universities. The final evaluation report published in 2011 contains an ex-post assessment (Wroblewski \& Leitner 2011). This focuses both on whether and how the financial incentive had contributed to increasing the share of women professors and whether and to what extent the gender dimension had been anchored in university appointment procedures for the long term to counteract a potential gender bias.

Evaluation design: The evaluation design is based on a mix of methods, university statistics (e.g. share of female professors, age distribution of professors), data collected by the universities themselves (e.g. on the share of women at different stages in an appointment procedure), university documents relating to appointment procedures (e.g. appointment guidelines, plan to advance women) as well as interviews with experts. The 22 universities in Austria were used as case studies, with the different data sources collated to establish as holistic a picture as possible of appointment procedures at each university.

\footnotetext{
$2 \quad$ Publication by the Federal Ministry of Education and Research of Guidelines on the Implementation of the Programme for Women Professors of the Federal Government and Länder to Promote Equal Opportunities for Women and Men at Higher Education Institutions in Germany - Programme for Women Professors II, 6.12.2012". 
Results: While the share of women professors rose significantly during the programme period (from $13 \%$ in the reference year 2003 to $19 \%$ in 2010), women representation did, however, remain below expectations, i.e. the targeted $26 \%$ share. A number of universities developed strategies to combat the underrepresentation of women in their appointment procedures (for an overview see Wroblewski, 2015). Some started by analysing the share of women at different stages of the procedure to detect potential sources for gender bias. Others sought to raise the share of women and prevent the early exit of women therein by introducing corresponding elements to promote women (e.g. active search for suitable female candidates, preferential invitation of women to hearings, gender-sensitive assessment criteria).

However, it should be noted that those universities with gendersensitive appointment procedures were not necessarily the ones that were able to raise their share of women professors most or received the highest bonus payments. A university's "success" in the excellentia context depended on a variety of factors over which the programme had little, if any, influence, such as the share of female professors prior to excellentia, the number of appointments in the programme timeframe, the subjects taught or the unforeseen vanishing of women professors (as a consequence of recruitment elsewhere or retirement).

A broad spectrum of possibilities for appointment procedures emerged in the course of the qualitative analysis (case studies) - despite the fact that the basics of this procedure were already laid down by UG 2002. The impact of an existing equal opportunities policy on the appointment procedure also became apparent. In other words, universities with established and comprehensive equal opportunities policies are more likely to also look for and address a potential gender bias in their appointment procedures. Such universities frequently already have an evidence-based discourse on equal opportunities, i.e. any corresponding lack/achievement of success is discussed on the basis of monitoring data (e.g. share of women professors).

\subsection{EVALUATION OF THE "PROGRAMME FOR WOM- EN PROFESSORS"}

Object of the evaluation: The German Federal Ministry of Education and Research formulated a total of three goals for the Programme for Women Professors (phases I and II, 2008 to 2017), namely the promotion of equality of women and men in higher education, a lasting rise in the share of women at all qualification levels in the higher education system and an increase in the number of women in top positions in higher education. Two of these goals directly target the promotion of women or their representation in the German higher education system. The basis for funding decisions is "forward-thinking equal opportunities concepts by the universities". ${ }^{4}$ A university can only receive start-up funding for up to three female professors if it submits a competitive equal opportunities concept. ${ }^{5}$ It then undertakes to use an equal amount of the funding obtained through the programme to implement equal opportunities measures at the university. These measures must in turn be described in the university's gender equality concept. In the first two phases of the programme (2008 to 2017), the federal government and the Länder made a total of 300 million euros available.

In phase II of the programme, different funding conditions apply for those universities that have already successfully obtained funding and appointed women professors in phase one, than for those that are submitting gender equality concepts for the first time. In the case of a second application, the universities submit a revised version of their concept along with documentation of the implementation of the concept previously submitted in phase one. In the case of a first application for programme funding in phase two, the universities submit a 'future-oriented equal opportunities concept', which details their previous efforts and successes in achieving "a lasting improvement in the representation of women".

Goal and purpose of the evaluation: The goal of the evaluations was to assess how the programme had been implemented and accepted by the universities on the one hand and to determine its direct and longterm impacts on the other (evaluation of phase II). In concrete terms and in line with the programme's goals, the evaluations focused on the impacts on equal opportunities for women and men, the improvement in the representation of women at all qualification levels and the increase in the number of women in top positions in the higher education system.

Evaluation design: The evaluation design for phase II of the programme and the concurrent full evaluation combine qualitative and quantitative social sciences methods with program data analysis. They differentiate between implementation of the programme, achievements, direct and long-term impacts, combining perspectives from the universities, the Länder and the ministry. In addition to document analyses, expert interviews and statistical analyses of programme data, the evaluation team assessed three different case studies (Löther \& Glanz, 2017).

Results: In the full evaluation, the number of applications for funding from the programme indicates a very high acceptance on the part of the universities. In phase I of the programme, 152 universities submitted an equal opportunities concept, with this number rising to 184 in phase II (including repeat applications). Through the funding provided by the programme, over 500 women professors have been appointed since 2008 (Löther \& Glanz, 2017; Zimmermann, 2012). After deduction of the expected annual increase rates, the Programme for Women Professors has brought about an additional increase of $2.2 \%$. Through the competitive nature of the call for applications and the link this triggered between gender policy and "excellence", the full evaluation identified good acceptance of and a general enhancement of the reputation of equal opportunities (Löther \& Glanz, 2017). An anchoring of equal opportunities policy can be seen in particular both in core university bodies and at management level; fewer concrete changes are evident at department level. A specific development of equal opportunities policy towards diversity and internationalisation can be identified at some universities in phase II of the programme. Here, an equal opportunities policy with a focus on human resources and international recruiting is emerging (Zippel \& Lipinsky, 2017).

\footnotetext{
$4 \quad$ Publication by the Federal Ministry of Education and Research of Guidelines on the Implementation of the Programme for Women Professors of the Federal Government and Länder to Promote Equal Opportunities for Women and Men at Higher Education Institutions in Germany - Programme for Women Professors II, 6.12.2012. 


\section{THE ROLE OF EVALUATION IN AN IMPACT- OR PERFORMANCE- ORIENTED SETTING}

Which steering effects can be determined for external evaluations in a competitive and performance-oriented setting? Does the external evaluation, its indicators and its notions of what constitutes "success" have an impact on how the university is managed? If so, how? Does the evaluation and/or the indicators used to evaluate the programme have an impact on higher education policy? Ultimately, these questions serve to determine how and at what levels in the organisation the universities dealt with the success criteria as defined in the evaluation.

A combination of management by objectives and monitoring creates a framework for a decentralised implementation of measures in universities. Both programmes described above focus on increasing the share of women professors. An analysis of the trends for quantified goals and corresponding indicators alone leaves the strategy behind such measures hidden in a "black box". The lack of an explicit discussion of mechanisms leading to impacts produces a situation in which impacts cannot be fully and specifically traced back to defined causes. In an ideal scenario, an evaluation contributes to revealing the reasons for and scope of any intended and unintended changes.

There is frequently also a political component to the commissioning of an evaluation: it underlines the relevance of the subject of the evaluation and can itself constitute an intervention, e.g. when primary data are collected during the evaluation (Wroblewski, Kelle, \& Reith, 2016). In the course of the evaluation of excellentia, expert interviews were conducted with university rectors, and the universities were asked to collect data on the representation of women in the different stages of the appointment procedure. The interviews raised awareness of the topic and challenged the broad assumptions that appointment procedures were based on objective criteria and were thus by definition sex and gender "neutral". After the interview, the rector of one university commissioned the quality management department to conduct a survey of appointment procedures in the previous year (share of women among applicants, in the assessment, in the hearing, on the shortlist). Other universities used the data collection process initiated by the evaluation to adapt their existing data collection systems and reflect on the quality of the data collected (Wroblewski \& Leitner, 2013). The indicators used in the evaluation are therefore also relevant from an internal management perspective, since they are incorporated into existing quality assurance systems and thus become part of the ongoing internal reporting on gender equality target achievement, i.e. flow into a gender policy discourse inside the university (Wroblewski 2015).

A direct comparison of its share of women professors with those of other EU Member States or the EU average raised the pressure on Germany to achieve "success" in its gender equality policies in the form of an increased representation of women (European Commission, 2016; European Commission - DG Research, 2014; Lipinsky \& Löther, 2016). Increasing the share of women professors constituted a main indicator of success in both evaluations of the Programme for Women Professors (Löther \& Glanz 2017; Zimmermann 2012). Given the legal requirement to intensify the recruitment of women professors, it is clear that existing legal instruments like e.g. the "recruitment quota" (whereby preference is to be given to a woman in case she is equally qualified as the best qualified male candidate) have not yet produced the desired results. The effect of the Programme for Women Professors for social and higher education politics thus (also) lies in its ability to counteract the shortcomings of existing (legal) instruments. Given the quantifiable success, there seems to be no need to improve the effectiveness of the recruitment quota or to reinforce targets for universities in form of the cascade model (cf. (Dalhoff \& Steinweg, 2010), since the increase in the share of female professors is partly being achieved through this programme.

\section{CLOSING REMARKS}

The aims of the introduction of a 'management by objectives' in gender equality policy and the development of a corresponding monitoring system are twofold: Firstly, to transfer responsibility for the development and implementation of gender equality policies from ministerial to university level and secondly, to raise the binding nature of targets through the ongoing monitoring of target achievement. In the two case studies described in this article, increasing the share of female professors plays an important role as key objective as well as central measurement indicator of "success" in equal opportunities policy in higher education.

Based on our case studies, a critical examination of the steering effect of quantitative indicators indicates their potential influence on the implementation of equal opportunities policy at a university. It also reveals the corresponding need for specific frameworks. A verified "programme success" can strengthen the university's orientation towards equal opportunities or "conceal" the lack of effectiveness of other (noncompetitive, non-financial) instruments. Whether or not such indicators will have a steering impact depends greatly on whether they are integrated into an institutional equal opportunities discourse and are compatible with other management instruments (e.g. the indicators used in quality management)

Identifying and utilising this steering potential requires a look inside such a programme's "black box", i.e. an analysis of the respective implementation processes and impact mechanisms such as that provided in our case studies through the qualitative analyses. This links the quantitative target criteria and their associated indicators with other indicators of success, producing a more comprehensive and conclusive analysis of impacts. With the knowledge of impact mechanisms thus generated, evaluations also deliver input for the development of future programmes - input that would not be possible with a reduced focus on the quantitative target criteria only.

\section{REFERENCE LIST}

Dalhoff, J., Lipinsky, A., Löther, A., \& Steinweg, N. (2015). Wissenschaftskultur und Wissenschaftspolitik: Eine Bestandsaufnahme im Herbst 2015. CEWSjournal. (100), 3-25, from http://www.gesis.org/ fileadmin/cews/www/CEWSjournal/cews-journal100.pdf.

Dalhoff, J., \& Steinweg, N. (2010). Leistungsabhängige, verbindliche und flexible Zielquoten für wissenschaftliche Führungspositionen (CEWS-Positionspapier No. Nr. 4). Bonn: Kompetenzzentrum Frauen in Wissenschaft und Forschung (CEWS). Retrieved December 06, 2016, from http://www.gesis.org/fileadmin/cews/www/download/cews-Position4-2teAufl.pdf. 
Deutsche Forschungsgemeinschaft (DFG) (2014). Forschungsorientierte Gleichstellungsstandards der DFG. Retrieved February 06, 2017, from Deutsche Forschungsgemeinschaft (DFG): http://www.dfg.de/foerderung/grundlagen_rahmenbedingungen/chancengleichheit/forschungsorientierte_standards/.

Engels, A. (September 2009). Gleichstellungsaspekte der Exzellenzinitiative. Workshop auf der 21. BUKOF-Jahrestagung 2009. Leipzig.

Engels, A., Beaufaÿs, S., Kegen, N. V., \& Zuber, S. (2015). Bestenauswahl und Ungleichheit: Eine soziologische Studie zu Wissenschaftlerinnen und Wissenschaftlern in der Exzellenzinitiative. Hochschule und Gesellschaft. Frankfurt am Main: Campus.

Engels, A., Ruschenburg, T., \& Zuber, S. (2012). Chancengleichheit in der Spitzenforschung : institutionelle Erneuerung der Forschung in der Exzellenzinitiative des Bundes und der Länder. In T. Heinze \& G. Krücken (Eds.), Organization \& Public Management. Institutionelle Erneuerungsfähigkeit der Forschung (pp. 187-217). Wiesbaden: Springer VS.

European Commission (2016). She Figures 2015: Gender in Research and Innovation. Luxembourg. Retrieved July 10, 2017, from http://ec.europa. eu/research/swafs/pdf/pub_gender_equality/she_figures_2015-final. pdf\#view=fit\&pagemode=none.

European Commission - DG Research (2014). Gender Equality Policies in Public Research: Based on a survey among Members of the Helsinki Group on Gender in Research and Innovation, 2013. Luxembourg. Retrieved April 05, 2016, from http://ec.europa.eu/research/ pdf/199627_2014\%202971_rtd_report.pdf.

Höllinger, S., \& Titscher, S. (Eds.) (2004). Die österreichische Universitätsreform. Zur Implementierung des Universitätsgesetzes 2002. Wien: WUV Universitätsverlag.

Kasparovsky, H. (Stand: 1. Jänner 2013). Universitätsgesetz 2002. Österreichisches Hochschulrecht Heft 14: BMWFW.

Kibler, S. (2011). Zwischen Emphase und Exklusion: Gleichstellungspolitik in der Exzellenzinitiative von 2005 bis 2007. Dissertation, Technische Universität CaroloĐWilhelmina zu Braunschweig, Braunschweig. Retrieved November 13, 2013, from http://digisrv-1.biblio.etc.tu-bs.de:8080/docportal/servlets/MCRFileNodeServlet/DocPortal_derivate_00020876/Dissertation_UB.pdf;jsessionid=1F95CB1D1F0D6E9950CCA0098BBADF1E.

Lipinsky, A. (2017). Gleichstellungsziele im deutschen Wissenschaftssystem zwischen Frauenförderung, Gender Mainstreaming, Anti-Diskriminierung, Diversität und Intersektionalität. In J. Dahmen \& A. Thaler (Eds.), Soziale Geschlechtergerechtigkeit in Wissenschaft und Forschung (pp. 23-38). Opladen, Berlin, Toronto: Budrich.

Lipinsky, A., \& Löther, A. (2016). Geschlecht und Gleichstellung in der Wissenschaft im europäischen Vergleich. Policies und statistische Daten. In Chancengleichheit in Wissenschaft und Forschung. 20. Fortschreibung des Datenmaterials (2013/2014) zu Frauen in Hochschulen und außerhochschulischen Forschungseinrichtungen (Materialien der GWK, pp. 1-33). Bonn,
Löther, A., \& Glanz, S. (2017). Evaluation des Professorinnenprogramms des Bundes und der Länder: Zweite Programmphase und Gesamtevaluation: Erweiterter Bericht (cews.publik No. 22). Köln. Retrieved October 17, 2017, from http://nbn-resolving.de/urn:nbn:de:0168-ssoar-54112-9.

Roßmann, S. (2013). Steuerung statt Legitimierung?: Über die Funktion(en) von Evaluationen staatlicher Forschungseinrichtungen für deren Zuwendungsgeber.

Simon, D. (2011). Gleichstellungspolitik als Element der Hochschulentwicklung: Anmerkungen zu den forschungsorientierten Gleichstellungsstandards. In B. Blättel-Mink, A. Franzke, \& A. Wolde (Eds.), Frankfurter Feministische Texte - Sozialwissenschaften: Vol. 14. Gleichstellung im Reformprozess der Hochschulen. Neue Karrierewege von Frauen an Hochschulen (pp. 109-120). Sulzbach i. Taunus: Helmer.

Tiefenthaler, B., \& Good, B. (2011). Genderpolitik in österreichischen Wissenschafts- und Forschungsinstitutionen. Synthesebericht zum Status quo an österreichischen Universitäten, Fachhochschulen, Privatuniversitäten und außeruniversitären Forschungseinrichtungen sowie Einrichtungen der Forschungsförderung: Studie im Auftrag des BMWF. Wien.

Weiss, C. H., Murphy-Graham, E., Petrosino, A., \& Gandhi, A. G. (2008). The fairy godmother - and her warts: Making the dream of evidence-based policy come true. American Journal of Evaluation, 29(1), $29-47$.

Wissenschaftsrat (2007). Empfehlungen zur Chancengleichheit von Wissenschaftlerinnen und Wissenschaftlern. Berlin. Retrieved 0ctober 23, 2012, from http://www.wissenschaftsrat.de/download/archiv/8036-07.pdf.

Wissenschaftsrat (2012). Fünf Jahre Offensive für Chancengleichheit von Wissenschaftlerinnen und Wissenschaftlern: Bestandsaufnahme und Empfehlungen. Köln: Wissenschaftsrat. Retrieved February 04, 2015, from http://www.wissenschaftsrat.de/download/archiv/2218-12.pdf.

Wroblewski, A. (2010). "Excellentia“: A programme to increase the share of women in leading positions in Austrian Universities. In L. Husu, J. Hearn, A.-M. Lämsä, \& S. Vanhala (Eds.), Leadership through the Gender Lens. Women and Men in Organisations (pp. 325-338). Helsinki: Hanken School of Economics.

Wroblewski, A. (2016). Gender-Indikatoren in der Wissensbilanz Grundlage für ein Gleichstellungsmonitoring oder Datenfriedhof? In A. Wroblewski, U. Kelle, \& F. Reith (Eds.), Gleichstellung messbar machen. Grundlagen und Anwendungen von Gender- und Gleichstellungsindikatoren (1st ed., pp. 171-189). Wiesbaden: Springer VS.

Wroblewski, A., Gindl, M., Leitner, A., Pellert, A., \& Woitech, B. (2007). Wirkungsanalyse frauenfördernder Maßnahmen im bm:bwk. Materialien zur Förderung von Frauen in der Wissenschaft: Bd. 21. Wien: Verlag Österreich.

Wroblewski, A., \& Leitner, A. (2007). Begleitende Evaluierung von "excellentia". 1. Zwischenbericht: Studie im Auftrag des BMWF. Wien: Institut für Höhere Studien (IHS). 
Wroblewski, A., \& Leitner, A. (2011). Equal Opportunities Policies at Austrian Universities and their Evaluation: Developments, Results and Limitations. Brussels Economic Review, 54(2/3). Retrieved August 02, 2011.

Wroblewski, A., \& Leitner, A. (2013). Analyse von Gender-Indikatoren: WB-Kennzahl 1.A.5 Gender Pay Gap und Datenbedarfskennzahl $1.3 \mathrm{Ge}-$ schlechterrepräsentanz im Berufungsverfahren: Studie im Auftrag des BMWF. Wien: Institut für Höhere Studien (IHS).

Zimmermann, K. (2012). Bericht zur Evaluation des „Professorinnenprogramm des Bundes und der Länder" (HoF-Arbeitsberichte No. 6'2012). Institut für Hochschulforschung (HoF). Retrieved June 25, 2015, from http://www.hof.uni-halle.de/dateien/ab_6_2012.pdf.

Zippel \& Lipinsky (2017) Fitting Diversity as Internationalization. 112th ASA meetings (unpublished conference presentation), August 15th, 2017 Montreal, Canada

\section{AUTHORS}

\section{ANGELA WROBLEWSKI}

Institut für Höhere Studien

Josefstädter Straße 39, 1080 Wien

Österreich

$+43159991135$

E: wroblews@ihs.ac.at

\section{ANKE LIPINSKY}

GESIS - Leibniz Institute for the Social Sciences

Dept. Monitoring Society and Social Change, CEWS

Unter Sachsenhausen 6-8, 50667 Köln

Germany

+4922147694259

E: anke.lipinsky@gesis.org 